\title{
Production of cupcake-like dessert containing microbial biosurfactant as an emulsifier
}

\author{
Ivison A Silva ${ }^{1,2}{ }^{2}$ Bruno O Veras ${ }^{1}$, Beatriz G Ribeiro ${ }^{1}$, Jaciana S Aguiar ${ }^{1}$, Jenyffer M Campos Guerra ${ }^{1}$, Juliana M \\ Luna $^{2,3}$, Leonie A Sarubbo ${ }^{\text {Corresp. } 2,3}$ \\ 1 Universidade Federal de Pernambuco, Recife, Pernambuco, Brazil \\ 2 Instituto Avançado de Tecnologia e Inovação (IATI), Recife, Pernambuco, Brazil \\ 3 Universidade Católica de Pernambuco, Recife, Pernambuco, Brazil \\ Corresponding Author: Leonie A Sarubbo \\ Email address: leonie.sarubbo@unicap.br
}

This work describes the application of the biosurfactant from Candida bombicola URM 3718 as a meal additive like cupcake. The biosurfactant was produced in a culture medium containing $5 \%$ sugar cane molasses, $5 \%$ residual soybean oil and $3 \%$ corn steep liquor. The surface and interfacial tension of the biosurfactant were $30.790 \pm 0.04 \mathrm{mN} / \mathrm{m}$ and $0.730 \pm$ $0.05 \mathrm{mN} / \mathrm{m}$, respectively. The yield in isolated biosurfactant was $25 \pm 1.02 \mathrm{~g} / \mathrm{L}$ and the $\mathrm{CMC}$ was $0.5 \mathrm{~g} / \mathrm{L}$. The emulsions of the isolated biosurfactant with vegetable oils showed satisfactory results. The microphotographs of the emulsions showed that increasing the concentration of biosurfactant decreased the oil droplets, increasing the stability of the emulsions. The biosurfactant was incorporated into the cupcake dessert formulation, replacing 50,75 and $100 \%$ of the vegetable fat in the standard formulation. Thermal analysis showed that the biosurfactant is stable for cooking cupcakes $\left(180^{\circ} \mathrm{C}\right)$. The biosurfactant proved to be promising for application in foods low in antioxidants and did not show cytotoxic potential in the tested cell lines. Cupcakes with biosurfactant incorporated in their dough did not show significant differences in physical and physicalchemical properties after baking when compared to the standard formulation. In this way, the biosurfactant has potential for application in the food industry as an emulsifier for flour dessert. 


\title{
Production of cupcake-like dessert containing microbial biosurfactant as an emulsifier
}

\author{
Ivison A. Silva ${ }^{1,2}$, Bruno O. Veras ${ }^{1}$, Beatriz G. Ribeiro ${ }^{1}$, Jaciana S. Aguiar ${ }^{1}$, Jenyffer M. Campos \\ Guerra $^{1}$, Juliana Moura de Luna ${ }^{2,3}$, Leonie A. Sarubbo ${ }^{2,3}$ \\ ${ }^{1}$ Universidade Federal de Pernambuco, Av. Prof. Moraes Rego, n. 1235, Cidade Universitária, CEP: \\ 50670-901, Recife, Pernambuco, Brasil \\ ${ }^{2}$ Instituto Avançado de Tecnologia e Inovação (IATI), Rua Joaquim de Brito, n. 216, Boa Vista, CEP: \\ 50070-280, Recife, Pernambuco, Brasil \\ ${ }^{3}$ Universidade Católica de Pernambuco, Rua do Príncipe, n. 526, Boa Vista, CEP: 50050-900, Recife, \\ Pernambuco, Brasil \\ Corresponding Author: \\ Leonie Sarubbo ${ }^{2,3}$ \\ Rua do Príncipe, n. 526, Boa Vista, CEP: 50050-900, Recife, Pernambuco, Brasil \\ Email address: leonie.sarubbo@unicap.br
}

\section{Abstract}

This work describes the application of the biosurfactant from Candida bombicola URM 3718 as a meal additive like cupcake. The biosurfactant was produced in a culture medium containing $5 \%$ sugar cane molasses, $5 \%$ residual soybean oil and 3\% corn steep liquor. The surface and interfacial tension of the biosurfactant were $30.790 \pm 0.04 \mathrm{mN} / \mathrm{m}$ and $0.730 \pm 0.05 \mathrm{mN} / \mathrm{m}$, respectively. The yield in isolated biosurfactant was $25 \pm 1.02 \mathrm{~g} / \mathrm{L}$ and the CMC was $0.5 \mathrm{~g} / \mathrm{L}$. The emulsions of the isolated biosurfactant with vegetable oils showed satisfactory results. The microphotographs of the emulsions showed that increasing the concentration of biosurfactant decreased the oil droplets, increasing the stability of the emulsions. The biosurfactant was incorporated into the cupcake dessert formulation, replacing 50, 75 and $100 \%$ of the vegetable fat in the standard formulation. Thermal analysis showed that the biosurfactant is stable for cooking cupcakes $\left(180^{\circ} \mathrm{C}\right)$. The biosurfactant proved to be promising for application in foods low in antioxidants and did not show cytotoxic potential in the tested cell lines. Cupcakes with biosurfactant incorporated in their dough did not show significant differences in physical and physical-chemical properties after baking when compared to the standard formulation. In this way, the biosurfactant has potential for application in the food industry as an emulsifier for flour dessert.

\section{Introduction}

In the era of globalization, biotechnology faces the challenge of producing biocompatible compounds that meet the needs of the current market (Kieliszek et al., 2017). In this context, the amphipathic natural additives produced by microorganisms and known as biosurfactants (Campos et al., 2014) stand out.

The use of biosurfactants in the food industry is due to their emulsifying, foaming, humectant and solubilizing properties, that is, these biomolecules can be used as emulsifiers in 
44

45

46

47

48

49

50

51

52

53

54

55

56

57

58

59

60

61

62

63

64

65

66

67

68

69

70

71

72

73

74

75

76

77

78

79

80

81

82

83

84

85

86

87

88

89

the processing of raw materials, in the control of the agglomeration of fat globules, in the stabilization of aerated systems and to improve the consistency of fat products (Salek \& Euston, 2019).

The industrial use of microbial biosurfactants, however, has been hampered due to the high production costs associated with inefficient recovery methods and the use of expensive substrates. However, these costs can be significantly reduced by using alternative sources of nutrients, as well as by obtaining high product yields and applying more economical extraction methods (Salek \& Euston, 2019). On the other hand, the food industry still does not use biosurfactants as additives on a large scale, as the regulation for approval of these biomolecules as a new food ingredient needs approval, which requires time and industrial investment.

Due to changes in the behavior of eating habits, ready-to-eat foods, often available as small units and known as "snackers", are becoming increasingly important. Examples of these products include donuts, muffins or cupcakes and cookies (Zouari et al., 2016).

Cupcakes are characterized by a long shelf life and can undergo changes in their composition in order to provide special dietary needs (Gupta et al., 2011). Another important aspect in the offering of desserts is its nutritional value, considering that consumer satisfaction is decisive for the success of a newly formulated product (Skrbic \& Cvejanov, 2011).

Trends in healthy eating and growing progress in research into functional natural food additives have been noted, including those that exhibit antioxidant activity without side effects compared to synthetic compounds (Abdel-Mawgoud \& Stephanopoulos, 2018; Bandyopadhyay et al., 2014). Thus, in order to reduce the use of synthetic emulsifiers or constituents of low nutritional value in foods, the use of biosurfactants has aroused industrial interest (Campos et al., 2013).

Among the micro-organisms that produce bioemulsifiers, yeasts of the genus Candida have been suggested due to their beneficial use in food. A major advantage of using yeasts is their GRAS (Generally Regarded as Safe) status, which classifies them as safe because they do not present risks of toxicity and pathogenicity (Campos et al., 2014).

In this sense, the objective of this work was to evaluate the addition of a biosurfactant with an emulsifying capacity to replace the vegetable fat used in the formulation of cupcakes with a view to providing a more biocompatible product for the food industries.

\section{Materials \& Methods}

Microorganism

The yeast Candida bombicola URM 3718, deposited in the Culture Collection of the Department of Mycology from Federal University of Pernambuco, was used in the production of the biosurfactant. Yeast maintenance was performed using Yeast Mold Agar (YMA) containing yeast extract $(0.3 \%)$, D-glucose $(1 \%)$, peptone $(0.5 \%)$ and agar $(2 \%), \mathrm{pH} 7.0$. The growth medium, Yeast Mold Broth (YMB), had the same composition, excluding agar.

\section{Biosurfactant production}

The yeast inoculum was standardized by transferring a loopful of the cream colored young culture to flasks containing $50 \mathrm{~mL}$ of YMB medium and incubated at $150 \mathrm{rpm}$ at $28{ }^{\circ} \mathrm{C}$ for 24 hours. After this period, dilutions were performed until the final concentration of $10^{4}$ cells $/ \mathrm{mL}$ was obtained, which was used in the concentration of $5 \%(\mathrm{v} / \mathrm{v})$. The biosurfactant was produced in a medium formulated with distilled water containing 5\% sugar cane molasses, $5 \%$ residual soybean frying oil and 3\% corn steep liquor, ( $\mathrm{pH} 6.0)$, as described by Freitas et al., (2016). The 
90 fermentations were carried out in $1000 \mathrm{~mL}$ Erlenmeyer flasks, containing $500 \mathrm{~mL}$ of the

91 production medium and incubated with the inoculum, under orbital shaking at $180 \mathrm{rpm}$ for 120

92 hours at $28^{\circ} \mathrm{C}$.

93

94

95

96

97

98

99

100

101

102

103

104

105

106

107

108

109

110

111

112

113

114

115

116

117

118

119

120

121

122

123

124

125

126

127

128

129

130

131

132

133

134

135

\section{Determination of surface and interfacial tension}

The surface tension of the biosurfactant was measured in the cell-free broth obtained after centrifugation at $5000 \mathrm{rpm}$ for $20 \mathrm{~min}$, in a KSV Sigma 700 (Finland) tensiometer employing the Du Nouy ring method at room temperature. The interfacial tension was measured in the same way in relation to $\mathrm{n}$-hexadecane.

\section{Isolation of biosurfactant}

A method developed in the laboratory was used, which initially consisted of extraction with ethyl acetate, twice, in the proportion 1:4 (v/v) of the non-centrifuged broth. Then, the organic phase was centrifuged (2600xg for 20 minutes) and filtered. The filtrate was transferred back to the separating funnel and a saturated $\mathrm{NaCl}$ solution was added to separate the remaining aqueous phase. The organic phase was transferred to an Erlenmeyer flask and anhydrous $\mathrm{MgSO}_{4}$ was added until granules were formed, which were filtered and dried at $50^{\circ} \mathrm{C}$.

\section{Composition of biosurfactant}

The biochemical composition of the isolated biosurfactant was determined as described by Luna et al. (2016). The protein concentration in the isolated biosurfactant was determined with bovine albumin as the standard. Total carbohydrate content was determined using the phenol-sulphuric acid method and lipids were quantified from extraction with chloroform: methanol at different proportions $(1: 1$ and $1: 2, \mathrm{v} / \mathrm{v})$.

\section{Critical Micelle Concentration (CMC)}

For this determination, $\mathrm{NaOH}$ diluted in distilled water was added to the crude extract of the biosurfactant, in the proportion 1:7 (v/v). Then, the product formed was washed with acetone, filtered and dried to evaporate the solvent. To obtain the CMC, $0.1 \mathrm{~g}$ of the product was weighed and successive dilutions with distilled water (concentrations of biosurfactant from 0 to $700 \mathrm{ppm}$ ) were performed and the surface tensions were determined in tensiometer (KSV Sigma 700, Finland) using the NUOY ring up to a constant value (standard deviation less than $0.4 \mathrm{mN} / \mathrm{m}$ during 10 successive measurements). The $\mathrm{CMC}$ was obtained by plotting surface tension against surfactant concentration and expressed as $\mathrm{g} / \mathrm{L}$ of biosurfactant.

\section{Emulsification activity}

The emulsification activity of the biosurfactant was compared with guar gum using the method described by Prasanna et al. (2012). Two $\mathrm{mL}$ of a vegetable oil (corn oil, soybean oil, sunflower oil, canola oil and peanut oil) were added to $2 \mathrm{~mL}$ of a solution of the biosurfactant at half the $\mathrm{CMC}(1 / 2 \mathrm{CMC})$, at the $\mathrm{CMC}$ and twice the $\mathrm{CMC}(2 \mathrm{xCMC})$ or solution of guar gum $(1 \%$, w/v) in a glass tube with screw cap and the contents were vortexed for 2 min at $50 \mathrm{~Hz}$. After $24 \mathrm{~h}$, the emulsification index $\left(\mathrm{E}_{24}\right)$ was determined according to Eq. 1:

$\mathrm{E}_{24}=\left(\mathrm{h}_{\mathrm{e}} / \mathrm{h}_{\mathrm{t}}\right) \times 100$ where: $h_{e}$ is the height of the emulsion layer and $h_{t}$ is the total height of the mixture, in mm. All samples were stored at $27^{\circ} \mathrm{C}$ (Han et al., 2015). 
136

137

138

139

140

141

142

143

144

145

146

147

148

149

150

151

152

153

154

155

156

157

158

159

160

161

162

163

164

165

166

167

168

169

170

171

172

173

174

175

176

177

178

179

180

181

\section{Light microscopy of emulsions}

The particle size distribution of the emulsions was measured using a modification of the method described by Prasanna et al. (2012). Briefly, an optical microscope (XSZ-HS3, Zhongyi Ltd, Beijing) was used to examine and photograph the emulsion after 24 hours of storage at $27^{\circ} \mathrm{C}$ through a 10x objective lens. A volume of $60 \mu \mathrm{L}$ of the emulsion was added to a slide and left to stand for 5 minutes for stabilization of the emulsion, followed by observation under the microscope (Han et al., 2015).

\section{Differential Scanning Calorimetry (DSC) and thermogravimetric analysis (TG)}

The thermal analysis of the biosurfactant $(50 \mathrm{mg}$ ) was performed according to Han et al. (2015), using a simultaneous thermal analyzer STA 449 F3 (NETZSCH). For this, successive heating / cooling / heating steps were performed, with a heating and cooling ratio of $10^{\circ} \mathrm{C} / \mathrm{min}$, in a nitrogen atmosphere with a flow rate of $50.0 \mathrm{~mL} / \mathrm{min}$, in the range of 40 at $400^{\circ} \mathrm{C}$.

\section{Antioxidant activity}

\section{Evaluation of the sequestering activity of the radical 2,2'-azino-bis (3-} ethylbenzothiazoline-6-sulfonate) (ABTS ${ }^{\circ+}$ )

This analysis was carried out following the methodology described by Re et al. (1999). The $\mathrm{ABTS}^{\bullet+}$ (Sigma-Aldrich, Dorset, UK) radical was formed by the reaction of $5 \mathrm{~mL}$ of the ABTS ${ }^{\bullet+}$ $7 \mathrm{mM}$ solution, with $88 \mu \mathrm{L}$ of the $140 \mathrm{mM}$ potassium persulfate solution, incubated at $25^{\circ} \mathrm{C}$ and in the absence of light for 16 hours. Once formed, the radical was diluted with P.A. ethanol until the absorbance value of $0.700 \pm 0.020$ at $734 \mathrm{~nm}$ was obtained. Different concentrations (156.25, $312.50,625.00,1250.00,2500.00$ and $5000.00 \mu \mathrm{g} / \mathrm{mL})$ of the biosurfactant $(10 \mu \mathrm{L})$ were mixed with $\mathrm{ABTS}^{\bullet+}$ solution $(1 \mathrm{~mL})$ and after 6 min incubation in the dark, the absorbances were read. Measurements were performed in triplicates and inhibition activities were calculated based on the percentage of $\mathrm{ABTS}^{\bullet+}$ sequestered. For the calibration curve, a standard solution of Trolox (6-hydroxy-2,5,7,8-tetramethychroman-2-carboxylic acid; Aldrich Chemical Co., Dorset, UK), a synthetic antioxidant analogous to vitamin E, was prepared at a concentration of 100 to 2000 $\mu \mathrm{M}$. The percentage of inhibition (I\%) was calculated using Eq. 2:

$\% \mathrm{I}=\left[\left(\mathrm{Abs}_{0}-\mathrm{Abs}_{1}\right) / \mathrm{Abs}_{0}\right] \times 100$ where $\mathrm{Abs}_{0}$ is the absorbance of the control and $\mathrm{Abs}_{1}$ is the absorbance of the compound.

\section{Evaluation of the sequestering activity of the 2,2-diphenyl-1-picrylhydrazyl radical (DPPH)}

The evaluation of the antioxidant activity of the biosurfactant by the free radical scavenging method was measured by means of hydrogen donation using the stable radical DPPH (Blois, 1958). A stock solution of methanolic DPPH $(200 \mu \mathrm{M})$ was further diluted in methanol to reach an UV-VIS absorbance between $0.6-0.7$ at $517 \mathrm{~nm}$, obtaining the DPPH working solution. Different concentrations of the composition $(40 \mu \mathrm{L})$ were mixed with DPPH solution $(250 \mu \mathrm{L})$ and after 30 min of incubation in the dark, the absorbances were read at the same wavelength mentioned above. The measurements were carried out in triplicates and the inhibition activities were calculated based on the percentage of DPPH eliminated. The percentage of inhibition (I\%) was calculated using Eq. 3:

$\mathrm{I} \%=\left[\left(\mathrm{Abs}_{0}-\mathrm{Abs}_{1}\right) / \mathrm{Abs}_{0}\right] \times 100$

Peer] reviewing PDF | (2020:02:46042:1:1:NEW 21 Mar 2020) 
182 where $\mathrm{Abs}_{0}$ is the absorbance of the control and $\mathrm{Abs}_{1}$ is the absorbance of the compound.

183 For the calibration curve, a standard Trolox solution was prepared, at a concentration of 10 to $184200 \mu \mathrm{M}$.

185

\section{Total antioxidant capacity by phosphomolybdenum}

187 The total antioxidant capacity (TAC) of the biosurfactant was evaluated by the phosphomolybdenum method, which consisted of the composition's ability to reduce molybdenum and form the phosphate-molybdate complex (Pietro et al., 1999). Different concentrations of the composition $(100 \mu \mathrm{L})$ were mixed in $1 \mathrm{~mL}$ with phosphate-molybdate complex ( $40 \mathrm{mM}$ ammonium molybdate / $60 \mathrm{mM}$ sulfuric acid, $280 \mathrm{mM}$ sodium phosphate), then incubated in a water bath at $90^{\circ} \mathrm{C}$ for 90 minutes. The absorbances were read on a spectrophotometer at $695 \mathrm{~nm}$. For calculation purposes, ascorbic acid was considered to has $100 \%$ antioxidant activity. The activity was calculated according to Eq. 4 :

$\%$ Active antioxidant $=\left[\left(\mathrm{Abs}_{1}-\mathrm{Abs}_{0}\right) / \mathrm{Abs}_{0}-\mathrm{Abs}_{\mathrm{AA}}\right] \times 100$ where $\mathrm{Abs}_{0}$ is the absorbance of the control, $\mathrm{Abs} s_{1}$ is the absorbance of the compound and $\mathrm{Abs}_{\mathrm{AA}}$ is the absorbance of ascorbic acid.

\section{Evaluation of the cytotoxic potential of the biosurfactant}

The MTT ((3-(4,5-dimethylthiazol-2-yl)-2,5-diphenyltetrazolium bromide) assay was carried out with mice fibroblast cells (L929) and renal epithelial cells of African green monkey (Vero), cell obtained from the Rio de Janeiro cell bank (Rio de Janeiro, Brazil), as described by Resende et al. (2019). The cells were detached with trypsin solution $(0.5 \%)$ and added at a concentration of $10^{5} / \mathrm{mL}$ to DMEM medium in a 96 -well microplate, followed by incubation at $37^{\circ} \mathrm{C}$ in a $5 \% \mathrm{CO}_{2}$ atmosphere for $24 \mathrm{~h}$. Next, $10 \mu \mathrm{L}$ of the isolated biosurfactant solutions at concentration of 6.25 , $12.50,25.00$ and $50.00 \mu \mathrm{g} / \mathrm{mL}$ were added, followed by incubation under the same atmospheric conditions for $72 \mathrm{~h}$. The negative control was DMEM and the positive control was phosphate buffer $(150 \mathrm{mmol} / \mathrm{L}, \mathrm{pH} 7.4)$. After $72 \mathrm{~h}, 25 \mu \mathrm{L}$ of MTT $(5 \mathrm{mg} / \mathrm{mL})$ stain was added and incubated for three hours. After incubation, the culture medium with MTT was aspirated and 100 $\mu l$ of dimethyl sulphoxide were added for the spectrophotometric reading at $560 \mathrm{~nm}$. The percentage inhibition was calculated using GraphPad Prism 7.0 demo software.

\section{Dough preparation and cupcakes baking}

Commercial samples of the following ingredients were purchased for processing the cupcakes: white wheat flour, vegetable fat (margarine) made from vegetable oils (palm and soy) and enriched with vitamins A and E ( $80 \%$ fat and 16\% moisture), refined sugar, fresh eggs, baking powder (containing sodium pyrophosphate, sodium bicarbonate and corn starch), skim milk powder and salt.

A cake dough formulation was used as a reference (Cross, 2006), according to Table 1. Vegetable fat and liquid whole egg were beaten with a N50 planetary mixer (Hobart GmbH, Offenburg, Germany) for $60 \mathrm{~s}$ (speed 3). The dry ingredients, weighed in a bowl and mixed with water were added to the pre-beaten vegetable fat/egg mass in the mixing unit and beat for more $60 \mathrm{~s}$. After filling the dough into paper forms in $50 \pm 0.2 \mathrm{~g}$ aliquots, the cupcakes were baked in a MIWE oven (Michael Wenz GmbH, Arnstein, Germany) for 24 min at $180^{\circ} \mathrm{C}$. After cooling, the cupcakes were stored in plastic bags until analysis (18-24 hours after cooking). From the reference formulation, $50 \%$ (formulation A), $75 \%$ (formulation B) and 100\% (formulation C) of 
227

228

229

230

231

232

233

234

235

236

237

238

239

240

241

242

243

244

245

246

247

248

249

250

251

252

253

254

255

256

257

258

259

260

261

262

263

264

265

266

267

268

269

270

vegetable fat was replaced by the biosurfactant. The cupcake formulations were processed in triplicate.

\section{Physical properties of cupcakes after baking}

Weight, diameter and height were evaluated. Weight was determined using a $0.001 \mathrm{~g}$ precision analytical balance (BEL Engineering). The diameter of the cupcakes was measured according to Noor Aziah et al. (2012). Four samples selected randomly were put next to one another and the total diameter was measured with a caliper (Mitiyoto Co. Tokyo, Japan). Then, all cupcakes were rotated by $90{ }^{\circ} \mathrm{C}$ and the new diameter was measured. The average of the two measurements divided by four was taken as the final diameter. The height of the cupcakes was also measured using a Digit CAL SI caliper (Mtx).

\section{Physical-chemical analysis of cupcakes after baking}

Test methodologies were used according to $A O A C$ (2002). The moisture content was determined using the gravimetric method, based on the weight loss of the samples submitted to heating in an oven at $105^{\circ} \mathrm{C}$ until constant weight. The total protein concentration was calculated using the Kjeldahl method, based on the acid digestion of organic matter followed by distillation, with nitrogen subsequently dosed by titration; and the nitrogen value multiplied by the 6.25 factor. For the fixed mineral residue (ashes) the gravimetric method was used, based on the determination of the weight loss of the samples submitted to incineration at $550{ }^{\circ} \mathrm{C}$.

To quantify the lipid fraction, the Bligh-Dyer cold extraction method (1959) was used, in which a mixture of chloroform, methanol and water is used. The carbohydrate content was obtained from the difference between 100 and the sum of the moisture, protein, lipid and ash determinations.

\section{Determination of the energy value of cupcakes after baking}

To determine the energy value, the mass values of carbohydrates, lipids and proteins were multiplied by 4, 9 and 4, respectively (Pires et al., 2017).

\section{Statistical analysis}

All analyzes were performed in triplicate. Means and standard errors were calculated using Microsoft Office Excel 2016. The Tukey Test, with 95\% confidence, was used in the physicalchemical analysis of formulated cupcakes.

\section{Results}

\section{Surface and interfacial tension}

The most important properties for verifying the effectiveness of a biosurfactant are related to surface and interfacial tensions. Biosurfactants work by reducing the forces that exist between molecules on the liquid's surface, exerting influence on hydrogen bonds and even on hydrophobic-hydrophilic interactions, thus increasing the contact surface (Bezerra et al., 2018). The results obtained for surface and interfacial tension for the biosurfactant produced by $C$. bombicola were $30.790 \pm 0.04 \mathrm{mN} / \mathrm{m}$ and $0.730 \pm 0.05 \mathrm{mN} / \mathrm{m}$, respectively. According to Akbari et al. (2018), biosurfactants with the ability to reduce the surface tension of water from 72 to 35 
$271 \mathrm{mN} / \mathrm{m}$ and the interfacial tension from 40 to $1 \mathrm{mN} / \mathrm{m}$ are effective, being considered good

272 surfactants.

273

274

275

Isolation and composition of biosurfactant

276

The biosurfactant was isolated from a procedure developed in the laboratory. The method has

277 advantages over other methods conventionally used for the extraction of biosurfactants, since initial stages of centrifugation and filtration are discarded, in addition to the use of a lower

278 volume of solvent (ethyl acetate). The biosurfactant yield obtained was $25.00 \pm 1.02 \mathrm{~g} / \mathrm{L}$. The

279 determination of the biochemical composition of the biosurfactant revealed the presence of $70 \%$

280

281

282 lipids and $30 \%$ carbohydrates.

\section{3}

284

285

286

287

288

289

290

291

292

293

294

295

296

297

298

299

300

301

302

303

304

305

306

307

308

309

310

311

312

\section{Critical Micelle Concentration (CMC)}

CMC corresponds to the lowest concentration of surfactant necessary to reduce surface tension as much as possible. This condition is reached when micelles start to form in solution and there is no further reduction in surface tension (Rocha e Silva et al., 2018).

The reduction in surface tension as a function of the concentration of biosurfactant is shown in Fig. 1. The CMC of the biosurfactant was determined as $0.5 \mathrm{~g} / \mathrm{L}$. CMC is related to the efficiency of surfactants and ranges from 0.001 to $2 \mathrm{~g} / \mathrm{L}$ for biosurfactants. Biosurfactants are more efficient as they have reduced CMC (Santos et al., 2016). Therefore, we can say that the $\mathrm{CMC}$ of the biosurfactant from C. bombicola is within the acceptable range for biosurfactants.

\section{Emulsification index $\left(\mathrm{E}_{24}\right)$}

The emulsification index $\left(\mathrm{E}_{24}\right)$ is a qualitative and fast method for evaluating the emulsifying properties of surfactants. Emulsion systems with hydrocarbons and / or water insoluble compounds are stabilized by surfactants. According to Campos et al. (2015), the stability of these emulsions is indicative of the activity of biosurfactants, although the emulsification capacity is not related to the ability to reduce surface tension.

The emulsifying capacity of the C. bombicola biosurfactant with different vegetable oils was compared with guar gum and the results are shown in Table 2. Guar gum was used as a comparison, since it has regulation documented by the FDA as an emulsifier for food purposes (Sharma et al., 2018). The results obtained indicate that both bioemulsifiers were able to satisfactorily emulsify the studied oils. The increase in the concentration of biosurfactant, as expected, increased the emulsification percentages.

\section{Particle size distribution of emulsions}

It is important that the emulsions formed in any process remain stable for marketing purposes. In this sense, the evaluation of the emulsion particle size distribution is necessary for the study of the physical properties of a biosurfactant, since it is possible to observe the emulsion droplet size (Luo et al., 2017; Han et al., 2015). The photomicrographs of the emulsions of the produced biosurfactant solutions ( $1 \frac{1}{2} \mathrm{CMC}, \mathrm{CMC}$ and $2 \mathrm{x}$ CMC) with vegetable oils are illustrated in Fig. 2. According to Kokal (2005), both the size of the droplets and the form of their distribution depends on related factors, including surface tension, nature of the emulsifier, properties of the 
313 oil used, in addition to the shear rate (mixtures, etc.). Analyzing Fig. 2, it is observed, in general, 314 that the increase in the concentration of biosurfactant was determinant for the decrease of the 315 droplets, which is related to the stability of the emulsion. It is also possible to observe that the 316 microphotographs for peanut oil showed a more uniform aspect regarding the size of the droplets, corroborating the results presented in Table 2, where the highest emulsification indexes were obtained.

319

\section{Differential Scanning Calorimetry (DSC) and Thermogravimetry (TG)}

The thermostability profile of the produced biosurfactant is shown in Fig. 3. Regarding the thermogravimetric analysis, it was possible to obtain the mass loss curve of the biosurfactant as a function of temperature. According to Fig. 3, the biosurfactant showed good thermal stability, with a loss of mass of $7.22 \%$ at a temperature of $181.76{ }^{\circ} \mathrm{C}$. Up to the final temperature $\left(400{ }^{\circ} \mathrm{C}\right)$, the variation in mass loss was in the range of $14.36 \%$.

For DSC analysis, the biosurfactant thermogram showed an exothermic peak with a crystallization temperature of $116.76^{\circ} \mathrm{C}$ (start temperature of $26.76^{\circ} \mathrm{C}$ ) and the endothermic melting peaks were observed at $186.76^{\circ} \mathrm{C}$ (start temperature at $141.76 \mathrm{C}$ ) and $319.26^{\circ} \mathrm{C}$ (start temperature at $291.76^{\circ} \mathrm{C}$ ).

\section{Antioxidant activity}

Lipid oxidation and enzymatic activities are problems of great significance in the food industry, which can result in changes in the chemical composition of the food, thus reducing its quality and shelf life. Antioxidants play a central role in neutralizing these processes, and their action can be verified through various mechanisms, that is, inhibiting free radicals, sequestering oxygen or chelating metal ions that catalyze oxidative reactions (Cörmet \& Gökmen, 2018).

Catches of organic radicals such as DPPH or reduction of complexes such as phosphomolybdenum, were determined and the percentages of total antioxidant capacity of the solutions of the biosurfactant are shown in Table 3. The biosurfactant showed promising results in relation to the technique of reduction of the phosphomolybdenum complex. Comparing the percentages of the total antioxidant capacity (TAC) of the biosurfactant with the reference concentration of ascorbic acid $(2000 \mu \mathrm{g} / \mathrm{mL})$, the biosurfactant showed $25.47 \%$ of activity. The results showed a linear relationship, indicating that the increase in the concentration of biosurfactant favors the increase in its activity. Thus, in higher concentrations, the biosurfactant produced has the potential for application in foods lacking in antioxidants.

From the DPPH test, the ability of the biosurfactant to prevent oxidation of the DPPH radical was evaluated. Analyzing Table 3, it is possible to observe again a linear relationship with the reduction percentages of the DPPH radical (\% I). Comparing the percentages with the Trolox reference, the biosurfactant showed $52.42 \%$ at a concentration of $1000 \mu \mathrm{g} / \mathrm{mL}$, demonstrating the potential for reducing the DPPH radical.

The third methodology used to determine the antioxidant profile of the biosurfactant was the method of sequestering the radical cation $\mathrm{ABTS}^{\bullet+}$ (Table 4). The biosurfactant did not present good percentages of inhibition of the radical in comparison with the standard Trolox, which was able to inhibit in $84.58 \%$, in the same concentration. Therefore, this test does not indicate the direct application of the biosurfactant as a sequester of the $\mathrm{ABTS}^{\bullet+}$ radical cation.

\section{Cytotoxic Evaluation}


358 Several microbial metabolites often have an adverse effect on host organisms, triggering

359 epidemic diseases, including neurotoxic and cytotoxic effects (Patowary et al., 2017). Therefore,

360 a cytotoxic evaluation of these metabolites is extremely important.

361 The results of percentage of cell viability obtained for the analyzed concentrations of the

362 biosurfactant are described in Table 5. It was observed that for both cell lines, the biosurfactant

363 showed cell viability above $90 \%$. According to Gomes Silva et al. (2017), inhibition percentages

364 from 1 to $20 \%$ are considered to be without inhibitory activity. Thus, the biosurfactant did not

365 show cytotoxic potential compared to the studied strains. ISO 10993-5, from 2009, determines

366 that a cell viability above $80 \%$ can be considered non-toxic in nature (ISO Report, 2009).

367

368

369

For the L929 strain, there were percentages of cell viability above $100 \%$. For MTT

testing especially this type of phenomenon is not uncommon. One reason for this may be the random experimental fluctuation, which should be between $+/-10 \%$; another reason is

370

371

372 stimulation by treatment. In the MTT assay, cell respiration is measured and its induction may indicate severe cell stress, since MTT is prone to compounds that interfere with energy metabolism, which can increase MTT metabolism to up to $200 \%$ of the base. A third reason,

although almost disposable, would be the direct chemical reduction of MTT by the biosurfactant; however, when this phenomenon occurs, the values are excessively high $(>500 \%)$.

375

\section{Characterization of cupcakes}

377

378

379

380

381

The visual appearance of the cupcakes after baking is illustrated in Fig. 4, while the physical properties are described in Table 6.

The results demonstrate that there were no major discrepancies between the different formulations in relation to the evaluated parameters. Thus, the partial or total replacement of vegetable fat by the biosurfactant did not cause significant changes in the physical properties of the cupcakes, despite the more pronounced fluctuation observed in the values found for Height, which remained within an acceptable margin. Visually (Fig. 4) there were also no major differences in cupcakes, which remained similar and attractive. Making a comparison with the values found in Height and Weight of the standard formulation versus formulations with the addition of biosurfactant, it is possible to observe that even noting a variation in the Height

\section{6} values, the respective weight measurements did not undergo significant changes. This was due to the fact that the reduction of fat used during the preparation of cupcakes decreases the amount of air bubbles that are incorporated into the dough and expand during cooking, resulting in an increase in the density of crumbs and, consequently, in an increase in dough (Zahn et al., 2010).

The results obtained for the physical-chemical composition and the energy value of the cupcakes are shown in Table 7. With respect to moisture, a significant decrease was observed between the three formulations proposed, with no significant difference between the standard formulations and formulation A. The vegetable fat used in the formulation of the cupcakes in this work, as an emulsion, is composed of an oily phase and an aqueous phase. As a consequence, cupcakes containing vegetable fat in their composition had a higher moisture content compared to cupcakes that contained biosurfactant in the formulation. Moisture can affect the shelf life of cupcakes, considering that it is related to the water activity present in the food, which favors microbial contamination.

There was no significant difference between the formulations regarding the levels of lipids found in the cupcake samples. Considering that the $C$. bombicola biosurfactant has a glycolipidic nature, all formulations presented a similar lipid content. However, it is possible to observe an increase in the percentage of lipids with the increase in the percentage of 
404 biosurfactant in cupcakes due to the lipid nature of glycolipids. It is important to note that about $40575 \%$ of the fatty acids of C. bombicola glycolipid are unsaturated (C18: 1, C18: 2 and C18: 3), 406 while the other $25 \%$ are saturated fatty acids (mainly C16: 0 ), unlike vegetable fat, which may 407 contain trans fatty acids, which increase cholesterol levels and cause cardiovascular disease 408 (Cavendish et al., 2009). Thus, it can be suggested that the replacement of vegetable fat by 409 biosurfactant allows an improvement in the quality of the formulated dessert.

410

Regarding the ash content, all formulations produced presented these different levels,

412 The addition of the biosurfactant also acted significantly in the reduction of the fixed mineral residue, since the commercialized industrial vegetable fat used in the formulations had about 550 $\mathrm{mg} / 100 \mathrm{~g}$ of product, representing a great contribution in the percentage of ash in the samples. Likewise, the protein content decreased as the incorporation of the biosurfactant increased.

The opposite effect was observed in relation to carbohydrates, that is, the increase in the concentration of biosurfactant from $75 \%$ favored the increase in the carbohydrate content in cupcakes. Since the biosurfactant is a glycolipid, it may have contributed to the increase in the carbohydrate content of the formulated product.

The energy value did not vary significantly between the standard formulation and formulations $\mathrm{A}$ and $\mathrm{B}$, and there was no difference between formulations $\mathrm{B}$ and $\mathrm{C}$. With the substitution of vegetable fat for biosurfactant, from $75 \%$, the carbohydrate content was higher, implying higher energy values. Zahn, et al. (2010) reported the replacement of fat in muffins by carbohydrates and obtained a reduction of about $45 \%$ in the content of lipids and, consequently, a reduction in the caloric value of the product.

Regarding the $\mathrm{pH}$ of the cupcakes, there was a decrease when the biosurfactant was added to the formulation in increasing concentrations, but this decrease did not affect the quality of the cupcakes. Reducing the $\mathrm{pH}$ can be considered an advantage, since more basic foods are more susceptible to microbial multiplication and, consequently, to deterioration $(J A Y, 2005)$.

Discussion

432 Analyzing the surface and interfacial tensions obtained in this work for the C. bombicola 433 biosurfactant with the values presented by Jadhav et al. (2019), using Starmerella bombicola 434 MTCC 1910 in medium containing 10\% sunflower oil residue, similar results can be observed, from $35.5 \pm 0.52 \mathrm{mN} / \mathrm{m}$ and $0.923 \pm 0.06 \mathrm{mN} / \mathrm{m}$ for surface and interfacial tensions, respectively. Similar results were also found by Shah et al. (2017) in a medium with 10\% palm oil, using Starmerella bombicola ATCC 22214, which obtained $35.35 \mathrm{mN} / \mathrm{m}$ for surface tension and $3.322 \pm 0.176 \mathrm{mN} / \mathrm{m}$ for interfacial tension. Values of $35.33 \pm 0.19 \mathrm{mN} / \mathrm{m}$ and $2.53 \pm 0.02$ $\mathrm{mN} / \mathrm{m}$ for surface and interfacial tensions, respectively, were found by Ribeiro et al. (2019) using the yeast $C$. utilis UFPEDA 1009 cultivated in a low-cost medium supplemented with 6\% residual canola oil, while Elshafie et al. (2015) using Candida bombicola ATCC22214 cultivated in glucose and corn oil observed that the biosurfactant produced reduced the both surface tension and interfacial tension to $28.56 \pm 0.42 \mathrm{mN} / \mathrm{m}$ and $2.13 \pm 0.09 \mathrm{mN} / \mathrm{m}$, respectively, within $72 \mathrm{~h}$. The sophorolipids produced by Starmerella bombicola cultivated in waste cooking oil reduced the surface tension to $32.6 \mathrm{mN} / \mathrm{m}$ and interfacial tension was $1.4 \mathrm{mN} / \mathrm{m}$ (Maddikeri et al., 2015). The yeast Sporisorium sp. aff. sorghi SAM20 produced approximately 32 g/L glycolipid biosurfactants from soybean oil after seven days. The critical micelle concentration and the surface tension at CMC were estimated to be $20 \mathrm{mg} / \mathrm{L}$ and $30.0 \mathrm{mN} / \mathrm{m}$, respectively (Alimadadi et al., 2018). 
450

451

452

453

454

455

456

457

458

459

460

461

462

463

464

465

466

467

468

469

470

471

472

473

474

475

476

477

478

479

480

481

482

483

484

485

486

487

488

489

490

491

492

493

494

Bacterial surfactants, on the other hand, such as rhamnolipids and surfactin, are capable to reduce the surface tension up to $25-26 \mathrm{mN} / \mathrm{m}$, and the interfacial tension to values as low as $0.001 \mathrm{mN} / \mathrm{m}$. Furthermore, they exhibit critical micelle concentrations considerably lower (10 $\mathrm{mg} / \mathrm{L}$ ) when compared with yeasts biosurfactants (Henkel et al., 2017; Li et al., 2017; Tan \& Li, 2018).

Regarding the isolation of the biosurfactant, Ribeiro et al. (2019) used the same extraction methodology for the isolation of biosurfactant produced by C. utilis UFPEDA 1009 and obtained $24.22 \pm 0.23 \mathrm{~g} / \mathrm{L}$. Pinto et al. (2018) obtained a yield of $61 \mathrm{~g} / \mathrm{L}$ using C. bombicola in a bioreactor, with the same extraction methodology used in this work, indicating the feasibility of this method to increase the yield of production in biosurfactant. Daverey \& Pakshirajan (2010), on the other hand, for $C$. bombicola cultivated in a medium containing mixed hydrophilic substrate (deproteinized whey and glucose), yeast extract and oleic acid, obtained 23.29 \pm 0.54 $\mathrm{g} / \mathrm{L}, 25.54 \pm 1.01 \mathrm{~g} / \mathrm{L}$ and $33.32 \pm 0.83 \mathrm{~g} / \mathrm{L}$ of biosurfactant when fermentation was carried out in batch shake flasks, in bioreactor without $\mathrm{pH}$ control and in bioreactor with $\mathrm{pH}$ control, respectively. The use of waste cooking oil as substrate to produce biosurfactants by Starmerella bombicola in a batch fermentation in the presence of ultrasound gave $24.7 \mathrm{~g} / \mathrm{L}$ of sophorolipids. The fed-batch mode of fermentation, on the other hand, gave $55.6 \mathrm{~g} / \mathrm{L}$ of sophorolipids (Maddikeri et al., 2015). Kaur et al. (2019) described that a high sophorolipid process efficiency was achieved by fed-batch fermentation using restaurant food waste hydrolysate as the batch medium. A sophorolipids titer of $115.2 \mathrm{~g} / \mathrm{L}$ was obtained in a fermentation time of $92 \mathrm{~h}$. Shah et al. (2017) used crude oils (Tapis oil, Melita oil, and Ratawi oil) as substrates for biosurfactant production by Starmerella bombicola. The sophorolipids yields using Tapis, Melita, and Ratawi oil were $26 \mathrm{~g} / \mathrm{L}, 21 \mathrm{~g} / \mathrm{L}$, and $19 \mathrm{~g} / \mathrm{L}$, respectively. The sophorolipids reduced the surface tension of pure water to $36.38 \mathrm{mN} / \mathrm{m}, 37.84 \mathrm{mN} / \mathrm{m}$, and $38.92 \mathrm{mN} / \mathrm{m}$, respectively, corresponding to critical micelle concentrations of $54.39 \mathrm{mg} / \mathrm{L}, 55.68 \mathrm{mg} / \mathrm{L}$, and $58.34 \mathrm{mg} / \mathrm{L}$.

The emulsification results against vegetable oils obtained in our work can be compared to the values found in the literature for emulsification indexes of biosurfactants from Candida species. Pinto et al. (2018), using C. bombicola to produce a biosurfactant from industrial waste obtained emulsification rates of $28 \%$ for canola oil, $26 \%$ for corn oil and $30 \%$ for soybean oil. Gaur et al. (2019) obtained 50, 50, 51 and 49\% emulsification for almond, mustard, soy and olive oil, respectively, for the C. glabrata biosurfactant CBS138. Campos et al. (2014), for the biosurfactant produced by $C$. utilis UFPEDA 1009 in medium containing residual canola oil, obtained 73, 73, 43 and 33\% of emulsification for sunflower, corn, soy and rice oils, respectively. The yeast Candida bombicola ATCC-22214 cultivated in a medium supplemented with coconut oil and glucose under fed-batch culture conditions produced $54.0 \mathrm{~g} / \mathrm{L}$ sophorolipids with significant surface activity $(25-35 \mathrm{mN} / \mathrm{m})$, and emulsion ability (Morya et al., 2013).

In the literature, it is not easy to find reports of thermostability in biosurfactants produced by C. bombicola; however, biosurfactants produced by species of bacteria have been characterized in terms of their thermostable profile. Kiran et al. (2017) analyzed the thermostability of the lipopeptide produced by Nesterenkonia sp and obtained similar results from melting peaks of $240{ }^{\circ} \mathrm{C}$ and $320^{\circ} \mathrm{C}$. The maximum loss of mass occurred at a temperature of $260{ }^{\circ} \mathrm{C}$, with $50.725 \%$. Singh \& Tiwary (2016) produced a biosurfactant from Pseudomonas otitidis $\mathrm{P} 4$ and observed that at a temperature of $149.9^{\circ} \mathrm{C}, 21.38 \%$ of the biosurfactant had been degraded. The crystallization temperature was similar to the temperature found for the $C$.

bombicola biosurfactant, that is, $112.83^{\circ} \mathrm{C}$.

Peer] reviewing PDF | (2020:02:46042:1:1:NEW 21 Mar 2020) 
495

496

497

498

499

500

501

502

503

504

505

506

507

508

509

510

511

512

513

514

515

516

517

518

519

520

521

522

523

524

525

526

527

528

529

530

531

532

533

534

535

536

537

According to Han et al. (2015), the higher the melting peak of the biosurfactants, the greater is their thermal stability. In addition, compounds that exhibit high degradation temperatures are more advantageous, since they are more resistant to extreme temperature conditions. Thus, knowing that the cupcakes cooking process takes place at a maximum temperature of $180^{\circ} \mathrm{C}$, it is possible to state that the biosurfactant will not suffer significant loss of mass, which makes its application feasible.

The literature does not describe the antioxidant activity with biosurfactants produced by the yeast $C$. bombicola. However, lipopeptides have been described as excellent antioxidants, mainly in relation to the elimination of the DPPH radical (Tabbene et al., 2012; Yalçin \& Çavuşoğlu, 2010). Ben Ayed et al. (2015) reported an interesting activity of eliminating DPPH radicals (65\%) of lipopeptides from Bacillus mojavensis A21. Another biosurfactant produced by Lactobacillus species showed sequestering activity of DPPH radicals around $75 \%$ at a concentration of $5000 \mu \mathrm{g} / \mathrm{mL}$ (Merghni et al., 2017). The biosurfactant from Streptomyces sp. showed a total antioxidant capacity of $80.4 \%$ at a concentration of $200 \mu \mathrm{g} / \mathrm{mL}$ (Ramrajan et al., 2017), while the mannosylerythritol lipids produced by Pseudozyma hubeiensis showed 50\% DPPH radical scavenging activity at $10 \mathrm{mg} / \mathrm{mL}$ and sequestration of superoxide ions greater than $50 \%$ under a concentration of $1 \mathrm{mg} / \mathrm{mL}$ (Takahashi et al., 2012). Thus, the biosurfactant produced by $C$. bombicola, which showed $52.42 \%$ activity at a concentration of $1000 \mu \mathrm{g} / \mathrm{mL}$, can be considered a good antioxidant, according to the DPPH radical scavenging method.

In the literature, it is common to find reports of bacterial biosurfactants that are non-toxic. For comparative purposes, the biosurfactant used in this work is derived from a yeast; however, it is important to mention some reports that may corroborate with the results found for the $C$. bombicola biosurfactant, since it is a glycolipid class biosurfactant, as described by Luna et al., (2016). Patowary et al., (2017) used a rhamnolipid produced by P. aeruginosa PG1 and obtained $85.6 \%$ cell viability for the mouse L292 fibroblast cell line. Another glycolipidic surfactant produced by Rhodococcus sp. 51T7 showed less toxicity than synthetic surfactants against 3T6 mouse fibroblasts (Marques et al., 2009).

\section{Conclusions}

The partial or total replacement of vegetable fat by the biosurfactant produced by C. bombicola URM 3718 did not drastically affect the final product, indicating the feasibility of applying this biomolecule in cupcakes formulation. The biosurfactant still has thermal stability, antioxidant properties and is non-toxic, being a potential additive for the food sector. The replacement of vegetable fat for biosurfactant can also improve the nutritional value of flour meal by reducing the trans fatty acids present in vegetable fat. The results obtained in this research demonstrate the feasibility of future studies focused on scale-up production of the biosurfactant, as well as conducting sensory studies aiming its future and promising application as an emulsifying additive for the food industry.

\section{Acknowledgements}

Authors like to thanks Lucas Rocha for his technical assistance.

\section{References}


538

539

540

541

542

543

544

545

546

547

548

549

550

551

552

553

554

555

556

557

558

559

560

561

562

563

564

565

566

567

568

569

570

571

572

573

574

575

576

577

578

579

580

581

582

583

Abdel-Mawgoud AM, Stephanopoulos G. 2018. Simple glycolipids of microbes: Chemistry, biological activity and metabolic engineering. Synthetic and Systems Biotechnology 3(1):3-19 DOI 10.1016/j.synbio.2017.12.001.

Akbari S, Abdurahman NH, Yunus R M, Fayaz F, Alara OR. 2018. Biosurfactants - a new frontier for social and environmental safety: a mini review. Biotechnology Research and Innovation 2(1):81-90 DOI 10.1016/j.biori.2018.09.001.

Alimadadi N, Soudi MR, Talebpour Z. 2018. Efficient production of tri-acetylated nonoacylated mannosylerythritol lipids by Sporisorium sp. Aff. Sorghi SAM20. Journal of Applied Microbiology 124(2):457-468 DOI 10.1111/jam.13642

AOAC. 2002. Association of Official Analytical Chemists. 17 ed. Washington, DC.

Bandyopadhyay K, Chakraborty C, Bhattacharyya S. 2014. Fortification of mango peel and kernel powder in cookies formulation. Journal of Academia and Industrial Research 2(12):661-664.

Ben Ayed H, Bardaa S, Moalla D, Jridi M, Maalej H, Sahnoun Z, Rebai T, Jacques P, Nasri M, Hmidet N. 2015. Wound healing and in vitro antioxidant activities of lipopeptides mixture produced by Bacillus mojavensis A21. Process Biochemistry 50(6):1023-1030 DOI 10.1016/j.procbio.2015.02.019.

Bezerra KGO, Rufino R D, Luna JM, Sarubbo LA. 2018. Saponins and microbial biosurfactants: potential raw materials for the formulation of cosmetics. Biotechnology Progress 34(6): 1482-1493 DOI 10.1002/btpr.2682.

Bligh EG, Dyer WJ. 1959. A rapid method of total lipid extraction and purification. Canadian Journal of Biochemistry and Physiology 37(8):911-917 DOI 10.1139/o59-099.

Campos JM, Stamford TLM, Rufino RD, Luna JM, Stamford TCM, Sarubbo LA. 2015. Formulation of mayonnaise with the addition of a bioemulsifier isolated from Candida utilis. Toxicology Reports 2:1164-1170 DOI 10.1016/j.toxrep.2015.08.009.

Campos JM, Stamford TLM, Sarubbo LA, Luna JM, Rufino RD, Banat IM. 2013. Microbial biosurfactants as additives for food industries. Biotechnology Progress 29(5):10971108 DOI 10.1002/btpr.1796.

Campos JM, Stamford TLM, Sarubbo LA. 2014. Production of a bioemulsifier with potential application in the food industry. Applied Biochemistry and Biotechnology 172(6):3234-3252 DOI 10.1007/s12010-014-0761-1.

Cavendish TA, Lemos PB, Yokota RT, Vasconcelos TF, Côelho PF, Buzzi M, Ito MK. 2010. Composição de ácidos graxos de margarinas à base de gordura hidrogenada ou interesterificada. Ciência e Tecnologia de Alimentos 30(1):138-142 DOI 10.1590/S010120612010005000018.

Cörmert ED, Gökmen V. 2018. Evolution of food antioxidants as a core topic of food science for a century. Food Research International 105:76-93 DOI 10.1016/j.foodres.2017.10.056.

Cross, N. 2006. Muffins and Bagels. In Hui YH. (Ed.). Bakery Products - Science and Technology (497-518). Oxford: Blackwell.

Daverey A, Pakshirajan K. 2010. Sophorolipids from Candida bombicola using mixed hydrophilic substrates: Production, purification and characterization. Colloids and Surfaces B: Biointerfaces 79:246-253 DOI 10.1016/j.colsurfb.2010.04.002

Elshafie A.E, Joshi SJ, Al-Wahaibi YM, Al-Bemani AS, Al-Bahry SN, Al-Maqbali D, Banat IM. 2015. Sophorolipids production by Candida bombicola ATCC 22214 and its potential application in microbial enhanced oil recovery. Frontiers in microbiology 6:1324 DOI 10.3389/fmicb.2015.01324

Peer) reviewing PDF | (2020:02:46042:1:1:NEW 21 Mar 2020) 
584

585

586

587

588

589

590

591

592

593

594

595

596

597

598

599

600

601

602

603

604

605

606

607

608

609

610

611

612

613

614

615

616

617

618

619

620

621

622

623

624

625

626

627

628

629

Freitas BG, Brito JGM, Brasileiro PPF, Rufino RD, Luna JM, Santos VA, Sarubbo LA. 2016. Formulation of a commercial biosurfactant for application as a dispersant of petroleum and by-products spilled in oceans. Frontiers in Microbiology 7:1646 DOI 10.3389/fmicb.2016.01646.

Gaur VK, Bajaj A, Regar RK, Kamthan M, Jha RR, Srivastava JK, Manickam N. 2019. Rhamnolipid from a Lysinibacillus sphaericus strain IITR51 and its potential application for dissolution of hydrophobic pesticides. Bioresource Technology 272:19-25 DOI 10.1016/j.biortech.2018.09.144.

Gomes Silva JA, Silva GC, Farias Silva MG, Farias Da Silva V, Aguiar JS, Gonçalves Da Silva T, Leite SP. 2017. Physicochemical characteristics and cytotoxic effect of the methanolic extract of Croton heliotropiifolius Kunth (Euphorbiaceae). African Journal of Pharmacy and Pharmacology 11(28):321-326 DOI 10.5897/AJPP2017.4798.

Han Y, Liu E, Liu L, Zhang B, Wang Y, Gui M, Wu R, Li P. 2015. Rheological, emulsifying and thermostability properties of two exopolysaccharides produced by Bacillus amyloliquefaciens LPL061. Carbohydrate Polymers 115:230-237 DOI 10.1016/j.carbpol.2014.08.044.

Henkel M, Geissler M, Weggenmann, Hausmann R. 2017. Production of microbial biosurfactants: Status quo of rhamnolipid and surfactin towards large-scale production. Biotechnology Journal 12:1600561 DOI 10.1002/biot.201600561

Jadhav JV, Pratap AP, Kale SB. 2019. Evaluation of sunflower oil refinery waste as feedstock for production of sophorolipid. Process Biochemistry 78:15-24. DOI 10.1016/j.procbio.2019.01.015.

Jay JM, Loessner MJ, Golden DA. 2005. Modern Food Microbiology. Springer, New York.

Kaur G, Wang H, To MH, Roelants SLKW, Soetaert W, Lin CSK. 2019. Efficient sophorolipids production using food waste. Journal of Cleaner Production 232:1-11. DOI 10.1016/j.jclepro.2019.05.326

Kieliszek M, Kot AM, Bzducha-Wrobel A, Błazejak S, Gientka I, Kurcz A. 2017. Biotechnological use of Candida yeasts in the food industry: A review. Fungal Biology Reviews 31(4):185-198 DOI 10.1016/j.fbr.2017.06.001.

Kiran GS, Priyadharsini S, Sajayan A, Priyadharsini GB, Poulose N, Selvin J. 2017. Production of lipopeptide biosurfactant by a marine Nesterenkonia sp. and its application in food industry. Frontiers in Microbiology 8:1138 DOI 10.3389/fmicb.2017.01138.

Kokal SL. 2005. Crude oil emulsions a state-of-the-art review. SPE Production and Facilities 20(1):5-13 DOI 10.2118/77497-pa.

Li Q. 2017. Rhamnolipid synthesis and production with diverse resources. Frontiers in Chemical Science and Engineering 11:27-36 DOI 10.1007/s11705-016-1607-x

Luna JM, Santos FAS, Rufino RD, Sarubbo LA. 2016. Production of biosurfactant from Candida bombicola URM 3718 for environmental applications. Chemical Engineering Transactions 49:583-588 DOI 10.3303/CET1649098.

Luo X, Zhou Y, Bai L, Liu F, Zhang R, Zhang Z, Zheng B, Deng Y, Mcclements DJ. 2017. Production of highly concentrated oil-in-water emulsions using dual-channel microfluidization: Use of individual and mixed natural emulsifiers (saponin and lecithin). Food Research International 96:103-112 DOI 10.1016/j.foodres.2017.03.013.

Maddikeri GL, Gogate PR, Pandit AB. 2015. Improved synthesis of sophorolipids from waste cooking oil using fed batch approach in the presence of ultrasound. Chemical Engineering Journal 263:479-487. DOI 10.1016/j.cej.2014.11.010

Peer) reviewing PDF | (2020:02:46042:1:1:NEW 21 Mar 2020) 
630

631

632

633

634

635

636

637

638

639

640

641

642

643

644

645

646

647

648

649

650

651

652

653

654

655

656

657

658

659

660

661

662

663

664

665

666

667

668

669

670

671

672

673

674

675

Marques A, Pinazo A, Farfan M, Aranda F, Teruel J, Ortiz A, Manresa A, Espuny M. 2009. The physicochemical properties and chemical composition of trehalose lipids produced by Rhodococcus erythropolis 51T7. Chemistry and Physics of Lipids 158(2):110-117 DOI 10.1016/j.chemphyslip.2009.01.001.

Merghni A, Dallel I, Noumi E, Kadmi Y, Hentati H, Tobji S, Amor A, Mastouri M. 2017. Antioxidant and antiproliferative potential of biosurfactants isolated from Lactobacillus casei and their anti-biofilm effect in oral Staphylococcus aureus strains. Microbial Pathogenesis 104:84-89 DOI 10.1016/j.micpath.2017.01.017.

Morya VK, Park J-H, Kim TJ, Jeon S, Kim E-Ki. 2013. Production and characterization of low molecular weight sophorolipid under fed-batch culture. Bioresource Technology 143:282-288 DOI 10.1016/j.biortech.2013.05.094

Noor Aziah AA, Mohamad Noor AY, Ho L-H. 2012. Physicochemical and organoleptic properties of cookies incorporated with legume flour. International Food Research Journal 19(4): 1539-1543.

Patowary K, Patowary R, Kalita MC, Deka S. 2017. Characterization of biosurfactant produced during degradation of hydrocarbons using crude oil as sole source of carbon. Frontiers in Microbiology 8:279 DOI 10.3389/fmicb.2017.00279.

Pietro P, Pineda M, Aguilar M. 1999. Spectrophotometric quantification of antioxidant capacity through the formation of a phosphomolybdenum complex: specific application to the determination of vitamin E. Analytical Biochemistry 269(2):337-341 DOI 10.1006/abio.1999.4019.

Pinto MIS, Ribeiro BG, Guerra JMC, Rufino RD, Sarubbo LA, Santos VA, Luna JM. 2018. Production in bioreactor, toxicity and stability of a low-cost biosurfactant. Chemical Engineering Transactions 64:595-600 DOI 10.3303/CET1864100.

Pires TCSP, Dias MI, Barros L, Ferreira ICFR. 2017. Nutritional and chemical characterization of edible petals and corresponding infusions: Valorization as new food ingredients. Food Chemistry 220:337-343. DOI 10.1016/j.foodchem.2016.10.026.

Prasanna PHP, Bell A, Grandison AS. 2012. Emulsifying, rheological and physicochemical properties of exopolysaccharide produced by Bifidobacterium longum subs. Infantis and CCUG 52486 and Bifidobacterium infantis NCIMB 702205. Carbohydrate Polymers 90(1):533-540 DOI 10.1016/j.carbpol.2012.05.075.

Ramrajan K, Ramakrishnan N, Tamizhazhagan V, Bhuvaneswari M. 2017. In vitro screenning and characterization of biosurfactant from marine Streptomyces sp. European Journal of Pharmacoly and Medicine Research 4:531-534.

Re R, Pellegrini N, Proteggente A, Pannala A, Yang M, Rice-Evans C. 1999. Antioxidant activity applying an improved ABTS radical cation decolorization assay. Free Radical Biology and Medicine 26(9-10):1231-1237 DOI 10.1016/S0891-5849(98)00315-3.

Resende AHM, Farias JM, Silva DDB, Rufino RD, Luna JM, Stamford TCM, Sarubbo LA. 2019. Application of biosurfactants and chitosan in toothpaste formulation. Colloids and Surfaces B: Biointerfaces 181:77-84. DOI 10.1016/j.colsurfb.2019.05.032

Ribeiro BG, Santos MM, Pinto MI, Meira HM, Durval IJB, Guerra JMC, Sarubbo LA. 2019. Production and optimization of the extraction conditions of the biosurfactant from Candida Utilis UFPEDA1009 with potential application in the food industry. Chemical Engineering Transactions 74:1477-1482 DOI 10.3303/CET1974247.

Rocha e Silva NMP, Meira HM, Almeida FCG, Silva RCFS, Almeida DG, Luna JM, Rufino RD, Santos VA, Sarubbo LA. 2018. Natural surfactants and their applications for

Peer) reviewing PDF | (2020:02:46042:1:1:NEW 21 Mar 2020) 
676

heavy oil removal in industry. Separation \& Purification Reviews 47(n): 1-15 DOI 10.1080/15422119.2018.1474477.

Sałek K, Euston S R. 2019. Sustainable microbial biosurfactants and bioemulsifiers for commercial exploitation. Process Biochemistry 85:143-155 DOI 10.1016/j.procbio.2019.06.027.

Santos DKF, Luna JM, Rufino RD, Santos VA, Sarubbo LA. 2016. Biosurfactants: multifunctional biomolecules of the 21st Century. International Journal of Molecular Sciences 17(3):401-430 DOI 10.3390/ijms17030401.

Shah MUH, Sivapragasam M, Moniruzzaman M, Talukder MMR, Yusup SB, Goto M. 2017. Production of sophorolipids by Starmerella bombicola yeast using new hydrophobic substrates. Biochemical Engineering Journal 127:60-67 DOI 10.1016/j.bej.2017.08.005.

Sharma G, Sharma S, Kumar A, Al-Muhtaseb SH, Naushad M, Ghfar AA, Mola GT, Stadler FJ. 2018. Guar gum and its composites as potential materials for diverse applications: A Review. Carbohydrate Polymers 199:534-545 DOI 10.1016/j.carbpol.2018.07.053.

Singh P, Tiwary BN. 2016. Isolation and characterization of glycolipid biosurfactant produced by a Pseudomonas otitidis strain isolated from Chirimiri coal mines, India. Bioresources Bioprocessing 3(1): 1-16 DOI 10.1186/s40643-016-0119-3.

Skrbic B, Cvejanov J. 2011. The enrichment of wheat cookies with high-oleic sunflower seed and hull-less barley flour: Impact on nutritional composition, content of heavy elements and physical properties. Food Chemistry 124(4):1416-1422 DOI 10.1016/j.foodchem.2010.07.101.

Tabbene O, Gharbi D, Slimene IB, Elkahoui S, Alfeddy NM, Cosette P, Mangoni ML, Jouenne T, Limam F. 2012. Antioxidative and DNA protective effects of bacillomycin Dlike lipopeptides produced by b38 strain. Biotechnology and Applied Biochemistry 168(8):2245-2256 DOI 10.1007/s12010-012-9933-z.

Takahashi M, Morita T, Fukuoka T, Imura T, Kitamoto D. 2012. Glycolipid biosurfactants, mannosylerythritol lipids, show antioxidant and protective effects against $\mathrm{H}_{2} \mathrm{O}_{2}$-Induced oxidative stress in cultured human skin fibroblasts. Journal of Oleo Science 61(8):457-464 DOI 10.5650/jos.61.457.

Tan YN, Li Q. 2018. Microbial production of rhamnolipids using sugars as carbon sources. Microbial Cell Factories, 17:89 DOI 10.1186/s12934-018-0938-3

Yalçin E, Çavuşoğlu K. 2010. Structural analysis and antioxidant activity of a biosurfactant obtained from Bacillus subtilis RW-I. Turkish Journal of Biochemistry 35:243-247.

Zahn S, Pepke F, Rohm H. 2010. Effect of inulin as a fat replacer on texture and sensory properties of muffins. International Journal of Food Science \& Technology 45(12):25312537 DOI 10.1111/j.1365-2621.2010.02444.x.

Zouari R, Besbes S, Ellouze-Chaabouni S, Ghribi-Aydi D. 2016. Cookies from composite wheat-sesame peels flours: Dough quality and effect of Bacillus subtilis SPB1 biosurfactant addition. Food Chemistry 194:758-769 DOI 10.1016/j.foodchem.2015.08.064. 


\section{Table $\mathbf{1}$ (on next page)}

Cupcake dough using standard formulation (100\% vegetable fat) and formulations A ( $50 \%$ vegetable fat $+50 \%$ biosurfactant), B ( $25 \%$ vegetable fat $+75 \%$ biosurfactant) and $\mathrm{C}$ (100\% biosurfactant). 


\begin{tabular}{lllll}
\hline \multirow{2}{*}{ Ingredients } & \multicolumn{1}{c}{ Doughs } \\
\cline { 2 - 5 } & \multicolumn{1}{c}{$\begin{array}{c}\text { Standard } \\
\mathbf{( g )}\end{array}$} & \multicolumn{1}{c}{$\begin{array}{c}\text { Formulation } \mathbf{A} \\
\mathbf{( g )}\end{array}$} & $\begin{array}{c}\text { Formulation B } \\
\mathbf{( g )}\end{array}$ & $\begin{array}{c}\text { Formulation C } \\
\mathbf{( g )}\end{array}$ \\
\hline Wheat flour & 153.66 & 153.66 & 153.66 & 153.66 \\
Sugar & 92.20 & 92.20 & 92.20 & 92.20 \\
Baking powder & 7.66 & 7.66 & 7.66 & 7.66 \\
Salt & 1.80 & 1.80 & 1.80 & 1.80 \\
Skim milk & 11.60 & 11.60 & 11.60 & 11.60 \\
powder & 77.00 & 38.50 & 19.25 & 0.00 \\
Vegetable fat & 46.10 & 46.10 & 46.10 & 46.10 \\
Liquid whole egg & 76.80 & 76.80 & 76.80 \\
water & 76.80 & 76.50 & 57.75 & 77.00 \\
Biosurfactant & 0.00 & 466.82 & 466.82 & 466.82 \\
Total & 466.82 & & & \\
\hline
\end{tabular}


Table 2 (on next page)

Emulsification index $\left(E_{24}\right)$ of guar gum and $C$. bombicola URM 3718 biosurfactant with vegetable oils. Data expressed as mean \pm S.D. of triplicate determinations. 


\begin{tabular}{lccccc}
\hline \multirow{2}{*}{$\begin{array}{l}\text { Guar gum } \\
\mathbf{( 1 \%}, \mathbf{p} / \mathbf{v})\end{array}$} & \multicolumn{5}{c}{$\mathbf{E}_{\mathbf{2 4}}(\mathbf{\%})$} \\
\cline { 2 - 6 } & Soybean oil & Corn oil & Canola oil & Sunflower oil & Peanut oil \\
\cline { 2 - 6 } & $48.11 \pm 1.33$ & $66.77 \pm 0.15$ & $52.59 \pm 1.05$ & $30.49 \pm 0.85$ & $42.36 \pm 1.38$ \\
\hline $\begin{array}{l}\text { Biosurfactant } \\
\text { concentration }\end{array}$ & $41.16 \pm 0.32$ & $39.29 \pm 0.00$ & $44.64 \pm 0.27$ & $49.78 \pm 0.31$ & $62.70 \pm 0.89$ \\
$\mathbf{1} / \mathbf{2 x C M C}$ & $45.81 \pm 3.50$ & $48.28 \pm 0.00$ & $45.44 \pm 1.40$ & $54.61 \pm 0.79$ & $68.97 \pm 0.00$ \\
CMC & $51.78 \pm 0.08$ & $56.33 \pm 0.48$ & $50.86 \pm 1.22$ & $56.72 \pm 2.19$ & $69.48 \pm 0.73$ \\
\hline
\end{tabular}




\section{Table 3 (on next page)}

Percentage of DPPH radical scavenging (\% I) and total antioxidant capacity (\% TAC) at different concentrations of the biosurfactant. Data expressed as mean \pm S.D. of triplicate determinations. 


\begin{tabular}{lcc}
\hline Biosurfactant concentration $(\boldsymbol{\mu g} / \mathbf{m L})$ & \% I & \% CAT \\
\hline $\mathbf{2 0 0 0 . 0 0}$ & - & $25.47 \pm 3.18$ \\
$\mathbf{1 0 0 0 . 0 0}$ & $52.42 \pm 0.69$ & $11.16 \pm 0.37$ \\
$\mathbf{5 0 0 . 0 0}$ & $32.93 \pm 0.59$ & $7.65 \pm 4.53$ \\
$\mathbf{2 5 0 . 0 0}$ & $25.05 \pm 0.67$ & $7.01 \pm 0.46$ \\
$\mathbf{1 2 5 . 0 0}$ & $8.48 \pm 1.16$ & $3.47 \pm 0.07$ \\
$\mathbf{6 2 . 5 0}$ & $4.55 \pm 0.35$ & $2.80 \pm 0.21$ \\
$\mathbf{3 1 . 2 5}$ & $2.32 \pm 0.90$ & - \\
\hline
\end{tabular}

1 


\section{Table 4 (on next page)}

Percentage of sequestration (\% I) of the radical 2,2'-azino-bis (3-ethylbenzothiazoline-6sulfonate) $\left(\mathrm{ABTS}^{\circ+}\right)$ by the biosurfactant. Data expressed as mean \pm S.D. of triplicate determinations. 


\begin{tabular}{lc}
\hline Biosurfactant concentration $(\boldsymbol{\mu g} / \mathbf{m L})$ & \% I \\
\hline $\mathbf{5 0 0 0 . 0 0}$ & $24.27 \pm 2.38$ \\
$\mathbf{2 5 0 0 . 0 0}$ & $17.40 \pm 0.49$ \\
$\mathbf{1 2 5 0 . 0 0}$ & $16.64 \pm 0.44$ \\
$\mathbf{6 2 5 . 0 0}$ & $3.36 \pm 0.71$ \\
$\mathbf{3 1 2 . 5 0}$ & $3.82 \pm 0.35$ \\
$\mathbf{1 5 6 . 2 5}$ & $0.61 \pm 2.73$ \\
\hline
\end{tabular}

1

2

3

4 


\section{Table 5 (on next page)}

Percentage of viability of the C. bombicola URM 3718 biosurfactant against the L929 and the Vero strains. 
1

\begin{tabular}{lcc}
\hline \multicolumn{1}{c}{ L929 } \\
\hline $\begin{array}{l}\text { Concentrations } \\
(\boldsymbol{\mu g} / \mathbf{m L})\end{array}$ & Celular viability $(\%)$ & $\begin{array}{c}\text { Satandard deviation } \\
(\%)\end{array}$ \\
\hline Control & 99.50 & 3.07 \\
$\mathbf{6 . 2 5}$ & 109.79 & 1.56 \\
$\mathbf{1 2 . 5 0}$ & 92.06 & 6.56 \\
$\mathbf{2 5 . 0 0}$ & 93.14 & 10.52 \\
$\mathbf{5 0 . 0 0}$ & 107.66 & 5.00 \\
\hline & Vero & \\
\hline Control & 99.82 & 1.96 \\
$\mathbf{6 . 2 5}$ & 94.72 & 3.32 \\
$\mathbf{1 2 . 5 0}$ & 96.54 & 3.43 \\
$\mathbf{2 5 . 0 0}$ & 98.37 & 4.79 \\
$\mathbf{5 0 . 0 0}$ & 95.93 & 0.72 \\
\hline
\end{tabular}




\section{Table 6(on next page)}

Physical properties of cupcakes after baking for the formulations tested. Data expressed as mean \pm S.D. of triplicate determinations. 


\begin{tabular}{|c|c|c|c|c|}
\hline Parameter & $\begin{array}{c}\text { Standard } \\
\text { formulation } \\
(\mathbf{1 0 0 \%} \text { vegetable } \\
\text { fat })\end{array}$ & $\begin{array}{c}\text { Formulation } A \\
\text { (50\% vegetable fat }+ \\
50 \% \text { biosurfactant })\end{array}$ & $\begin{array}{c}\text { Formulation B } \\
\text { (25\% vegetable } \\
\text { fat }+75 \% \\
\text { biosurfactant })\end{array}$ & $\begin{array}{c}\text { Formulation C } \\
(\mathbf{1 0 0} \% \\
\text { biosurfactant })\end{array}$ \\
\hline Weight (g) & $44.841 \pm 0.05$ & $44.955 \pm 0.22$ & $43.712 \pm 0.01$ & $44.576 \pm 0.29$ \\
\hline $\begin{array}{l}\text { Height } \\
\text { (mm) }\end{array}$ & $41.265 \pm 1.18$ & $35.975 \pm 1.93$ & $45.885 \pm 0.94$ & $42.435 \pm 0.35$ \\
\hline $\begin{array}{l}\text { Diameter } \\
(\mathrm{mm})\end{array}$ & $59.120 \pm 0.25$ & $57.630 \pm 0.01$ & $59.400 \pm 0.36$ & $57.610 \pm 0.68$ \\
\hline
\end{tabular}




\section{Table 7 (on next page)}

Physical-chemical composition and energy value of cupcakes for the tested formulations. Data expressed as mean \pm S.D. of triplicate determinations.

Means in the same line with different letters are significantly different $(p \leq 0.05)$ according to the Tukey Test. 
1

\begin{tabular}{lllll}
\hline Parameter & $\begin{array}{c}\text { Standard } \\
\text { formulation } \\
(\mathbf{1 0 0 \%} \text { vegetable } \\
\text { fat) }\end{array}$ & $\begin{array}{c}\text { Formulation A } \\
\mathbf{( 5 0 \% \text { vegetable }} \\
\text { fat }+\mathbf{5 0 \%} \\
\text { biosurfactant) }\end{array}$ & $\begin{array}{c}\text { Formulation B } \\
(\mathbf{2 5 \%} \text { vegetable } \\
\text { fat }+\mathbf{7 5 \%} \\
\text { biosurfactant) }\end{array}$ & $\begin{array}{c}\text { Formulation C } \\
(\mathbf{1 0 0 \%} \\
\text { biosurfactant) }\end{array}$ \\
\hline Moisture (\%) & $26.43 \pm 0.28^{\mathrm{a}}$ & $26.25 \pm 0.35^{\mathrm{a}}$ & $20.75 \pm 0.07^{\mathrm{b}}$ & $19.45 \pm 0.21^{\mathrm{c}}$ \\
Lipids (\%) & $19.72 \pm 1.94^{\mathrm{a}}$ & $18.61 \pm 3.25^{\mathrm{a}}$ & $19.15 \pm 0.49^{\mathrm{a}}$ & $22.50 \pm 0.56^{\mathrm{a}}$ \\
Ashes (\%) & $2.50 \pm 0.02^{\mathrm{a}}$ & $2.07 \pm 0.01^{\mathrm{b}}$ & $1.95 \pm 0.00^{\mathrm{c}}$ & $1.72 \pm 0.03^{\mathrm{d}}$ \\
Proteins (\%) & $6.86 \pm 0.0^{\mathrm{a}}$ & $6.45 \pm 0.08^{\mathrm{b}}$ & $4.14 \pm 0.01^{\mathrm{c}}$ & $3.17 \pm 0.02^{\mathrm{d}}$ \\
Carbohydrates (\%) & $44.88 \pm 1.62^{\mathrm{a}}$ & $46.60 \pm 2.99^{\mathrm{ac}}$ & $54.01 \pm 0.41^{\mathrm{b}}$ & $53.15 \pm 0.41^{\mathrm{bc}}$ \\
Energy value (kcal) & $382.86 \pm 10.90^{\mathrm{a}}$ & $379.73 \pm 17.62^{\mathrm{a}}$ & $404.95 \pm 2.76^{\mathrm{ab}}$ & $427.80 \pm 3.53^{\mathrm{b}}$ \\
pH & $8.19 \pm 0.01^{\mathrm{a}}$ & $6.60 \pm 0.00^{\mathrm{b}}$ & $6.50 \pm 0.00^{\mathrm{c}}$ & $6.30 \pm 0.00^{\mathrm{d}}$ \\
\hline
\end{tabular}
2 
Figure 1

Critical Micelle Concentration (CMC) of the biosurfactant isolated from Candida bombicola URM 3718. 


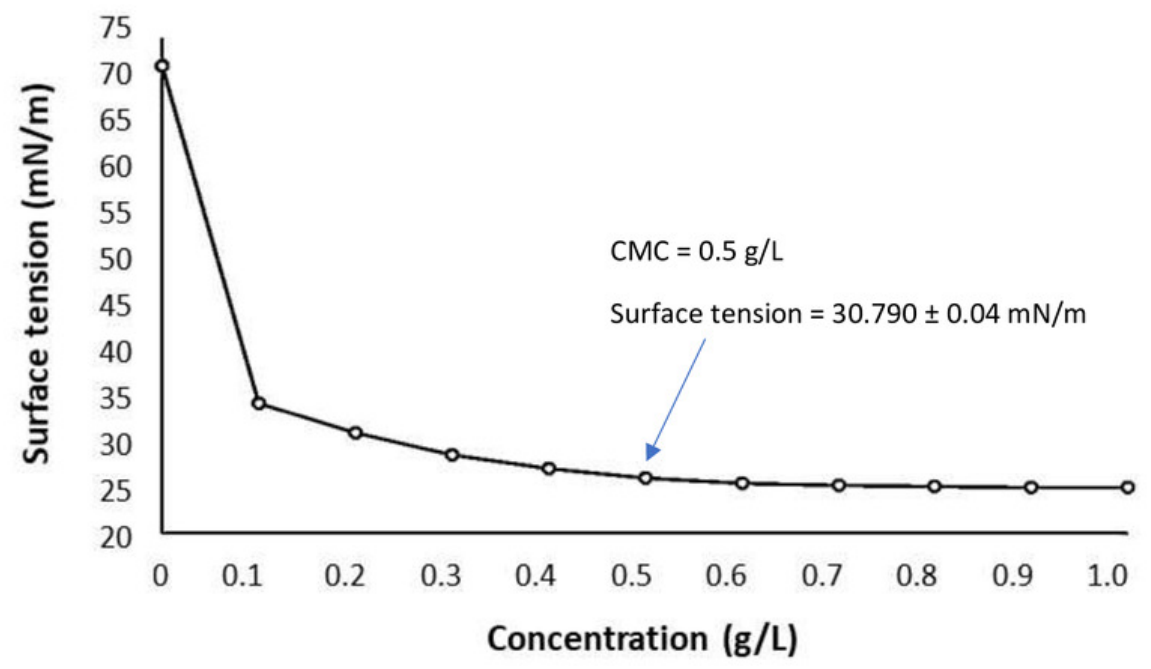


Figure 2

Photomicrograph of the emulsions formed by the biosurfactant in different concentrations for the following vegetables oils: (a-c) peanut; (d-f) canola; $(\mathrm{g}-\mathrm{i})$ soybean; (j-l) sunflower and (m-o) corn. 

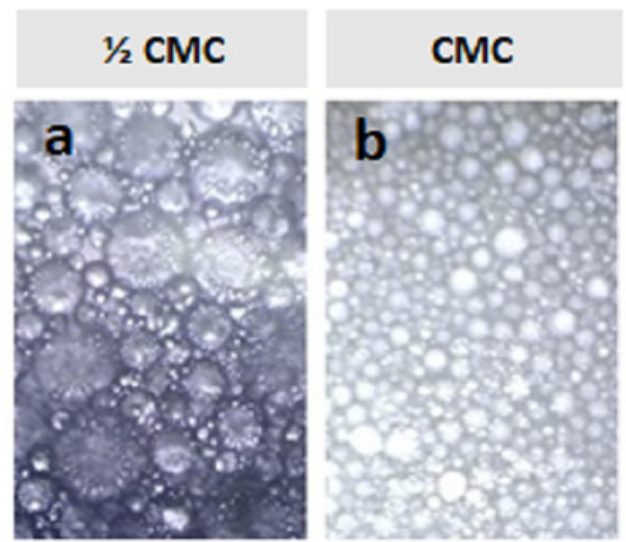

\section{$2 \times \mathrm{CMC}$}
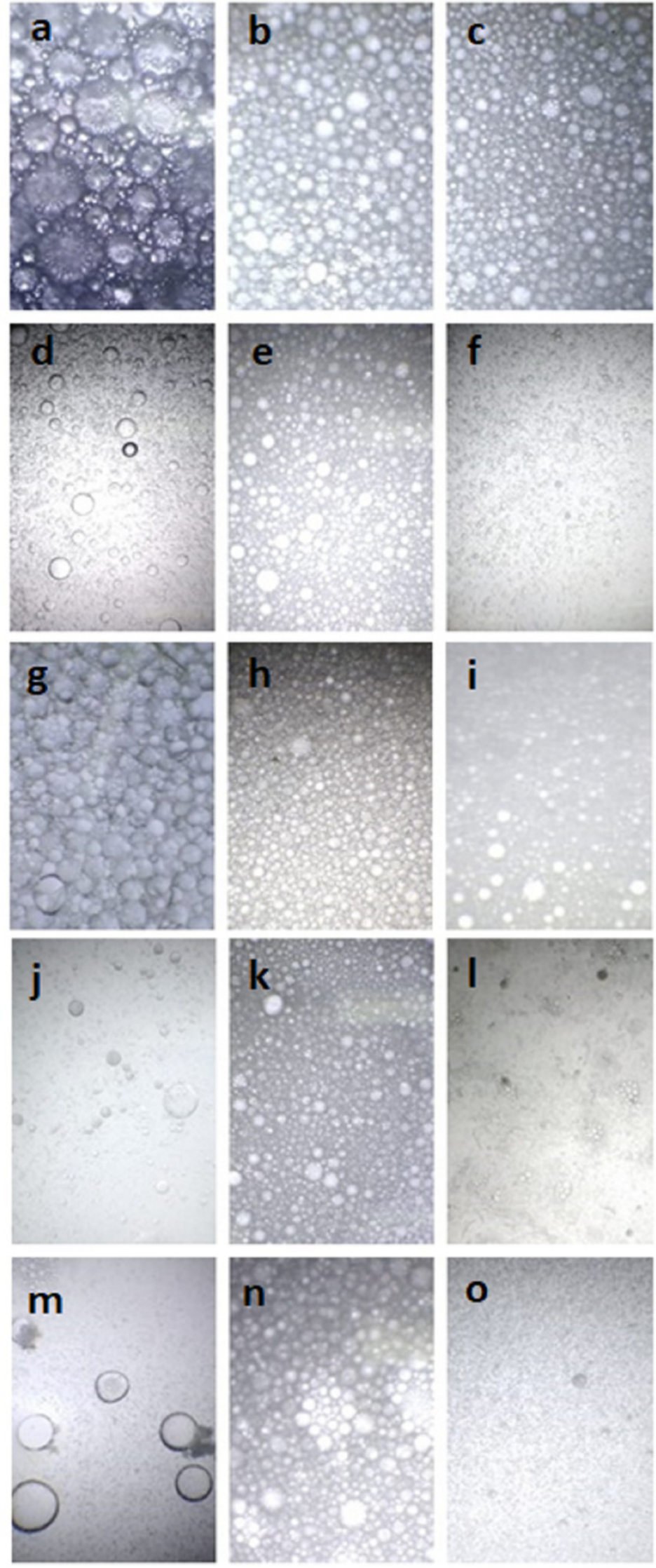

Peer) reviewing PDF | (2020:02:46042:1:1:NEW 21 Mar 2020) 
Figure 3

DSC and TG of the C. bombicola URM 3718 biosurfactant. 


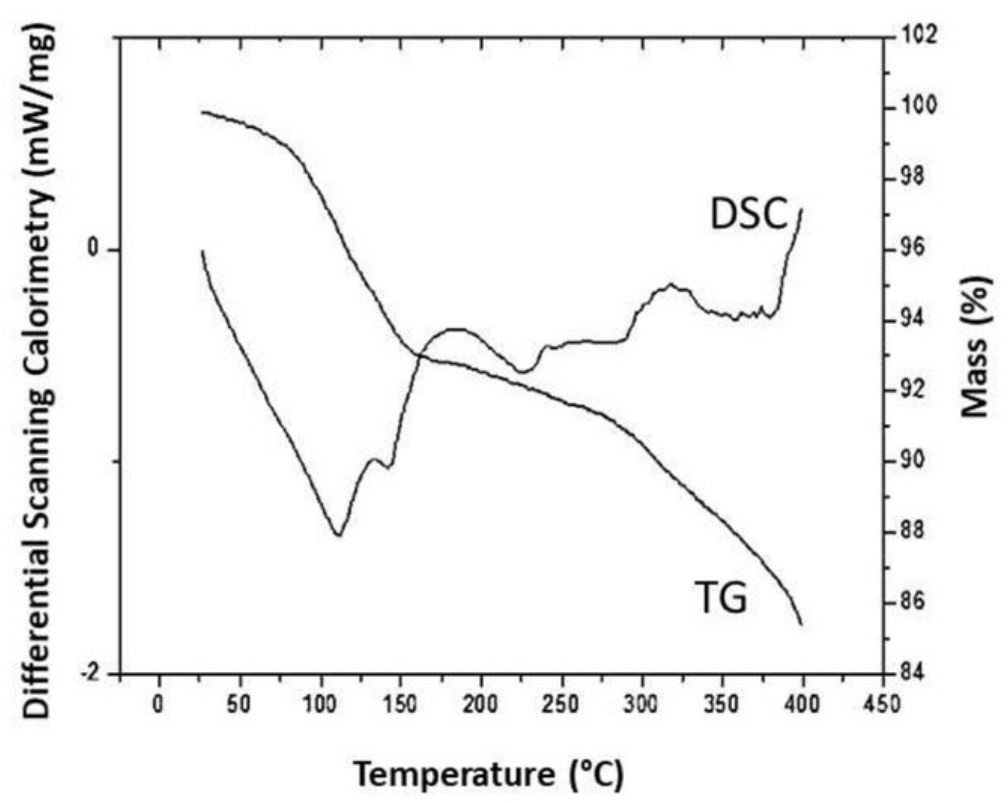


Figure 4

Cupcakes after baking. (a): standard formulation; (b): formulation A; (c): formulation B and (d): formulation C. 


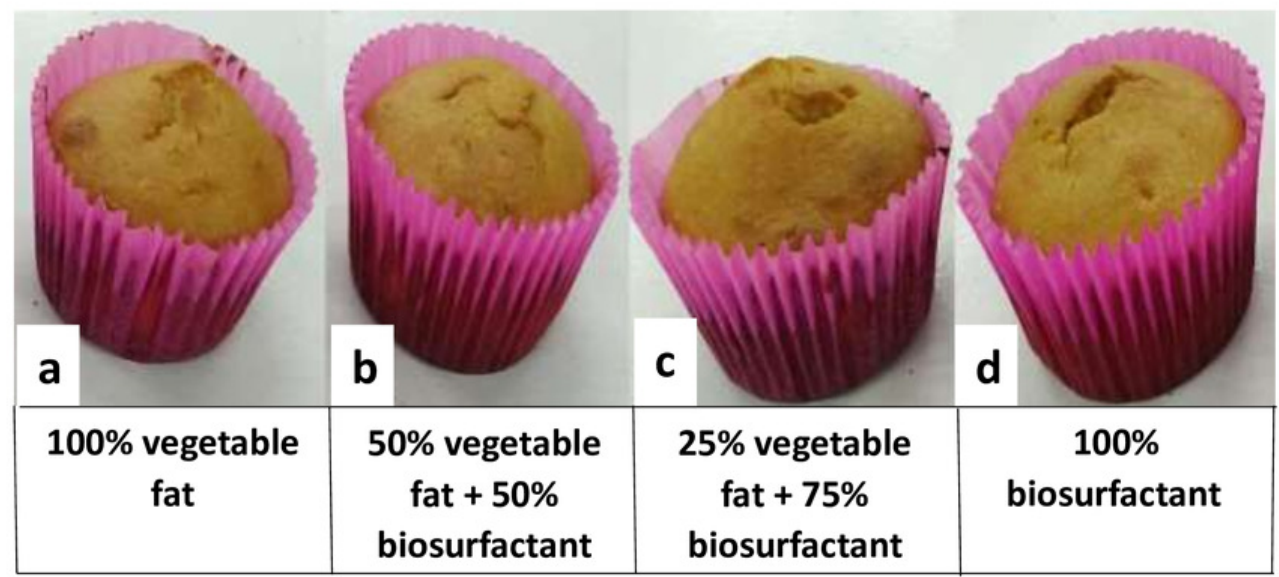

